\title{
VROUWENARBEID IN DE VROEGMODERNE TIJD IN NEDERLAND
}

\begin{abstract}
Women's work in the early modern Netherlands
This article first gives an overview of the context and the main research questions concerning female labour market participation in the Dutch Republic by introducing the IIS H research project on women's work. Then, it outlines the historiography of women's work and discusses new approaches. The history of women's work has long been described in terms of continuity or change of the position of women on the labour market. Yet, this context seems to be too limited to describe and explain women's labour market participation. Recent research, as well as the contributions to this volume, suggest that more is to be expected from local and regional studies, a comparative perspective, and attention for different groups of women. It is important to enlarge our empirical knowledge and integrate gender to get a better understanding of the early modern labour market.
\end{abstract}

De observaties van buitenlanders zijn al vaak aangehaald als het gaat om de positie van Hollandse vrouwen in de Vroegmoderne Tijd. Reizigers uit Engeland, Duitsland, Italië, Frankrijk en Spanje die in de zestiende, zeventiende of achttiende eeuw de Republiek bezochten, verbaasden zich over de opmerkelijke aanwezigheid van Nederlandse vrouwen in de openbare ruimte. Ze zagen zelfstandige, actieve onderneemsters die voor eigen rekening de zaken be-

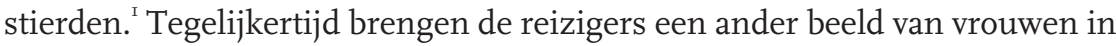
de Republiek naar voren: het beeld van de ijverige huisvrouw die het stoepje schrobde, het huis poetste en geobsedeerd was door properheid. ${ }^{2}$ Beschouwd vanuit ons hedendaagse perspectief zijn deze beelden moeilijk te rijmen. Maar er is nog te weinig bekend om te bepalen welk van beide typeringen het beste overeenkomt met de vroegmoderne praktijk. Jan de Vries en Ad van der Woude

1. Zie bijvoorbeeld: William Montague, The delights of Holland: or, a three months travel about that and the other provinces (Londen $\mathrm{I}_{9} 6$ 6) I83; J.N. Jacobsen Jensen, 'Moryson's reis door en zijn karakteristiek van de Nederlanden', in: Bijdragen en Mededelingen van het Historisch Genootschap 39 (I918) 272.

2. Zie: Simon Schama, The embarrassment of riches. An interpretation of Dutch culture in the Golden Age (Londen I991) 376-378. 
bijvoorbeeld, stellen in de paragraaf voorafgaand aan het hoofdstuk over de arbeidsmarkt in hun overzichtswerk over de economische geschiedenis van Nederland (I500-I8I5) uit I995:

Op de keper beschouwd past het onderwerp vrouwen- en kinderarbeid beter in het volgende hoofdstuk, waarin de arbeidsmarkt ter sprake komt. Het probleem is echter dat onze kennis van de bijdrage van vrouwen- en kinderarbeid aan het functioneren van de arbeidsmarkt veel te beperkt is om op zinvolle wijze in de analyse van die markt betrokken te kunnen worden. ${ }^{3}$

Om in deze lacune te voorzien ging op het I ISG het onderzoeksproject 'Vrouwen en werk in de Noordelijke Nederlanden in de Vroegmoderne Tijd' van start. $^{4}$

Kort na de start van dit project werd een studiedag georganiseerd. Het doel ervan was tweeledig. Enerzijds wilden we het recente onderzoek inventariseren. Anderzijds wilden we weten hoe vruchtbaar het traditionele debat over verandering of continuïteit van de positie van vrouwen op de arbeidsmarkt eigenlijk nog is. De lezingen van die studiedag zijn bewerkt tot de artikelen in deze bundel over het werk van vrouwen in (vooral de Noordelijke) Nederlanden in de Vroegmoderne Tijd (circa I550-I8I5).

In de volgende paragraaf wordt het IISG-onderzoeksproject geïntroduceerd om een indruk te geven van de context van het onderzoek naar werkende vrouwen in de Republiek. Daarna volgt een bespreking van de historiografie van vrouwen en werk en ga ik in op de aan te bevelen benadering. Het perspectief van verandering óf continuïteit van 'de positie' van werkende vrouwen lijkt achterhaald. Meer is te verwachten van nieuwe benaderingen uit recente onderzoeken: regionaal opgezette studies, comparatief onderzoek, aandacht voor lokale en regionale verschillen en verschillen tussen vrouwen onderling, waarbij nadrukkelijker aansluiting wordt gezocht bij debatten buiten vrouwengeschiedenis. Doel van dit perspectief is niet alleen om een beeld te krijgen van het werk van vrouwen. Ook moet vergroting van de kennis uiteindelijk leiden tot werkelijke integratie van de informatie, zodat arbeid bekeken kan worden vanuit het genderperspectief en we een beter inzicht krijgen in de vroegmoderne arbeidsmarkt. De geschiedenis van arbeid is niet sekseloos, maar dat blijft onduidelijk zolang de informatie over werkende vrouwen in algemene publicaties in aparte paragrafen staat vermeld.

3. Jan de Vries en Ad van der Woude, Nederland 1500-1815. De eerste ronde van moderne economische groei (Amsterdam I995) 689.

4. Dit onderzoeksproject wordt gefinancierd door de Stichting Vrienden van het I I S G, N wo en De Stichting Van Winterfonds en uitgevoerd door Elise van Nederveen Meerkerk, Marjolein van Dekken, Danielle van den Heuvel, Lotte van de Pol en Ariadne Schmidt. 
Vooraf zijn nog enkele opmerkingen over gemaakte keuzes op zijn plaats. Het werk van vrouwen staat centraal. Vrouwenarbeid en mannenarbeid kunnen niet altijd los van elkaar worden gezien. Zelfs als er geen verband in de praktijk bestond, dan nog stond dat wat men als 'vrouwenarbeid' definieerde in nauw verband met ideeën over wat als 'mannenarbeid' werd beschouwd. $\mathrm{Nu}$ en dan komt de relatie tussen beide aan de orde. Maar de achterstand in de kennis over het werk van vrouwen in de Vroegmoderne Tijd verklaart de keuze voor de aandacht voor vrouwen.

Dit themanummer richt zich op het werk van vrouwen dat een inkomen of omzet opleverde. Een belangrijk deel van het werk van vrouwen blijft daardoor buiten beschouwing. Veel werk van vrouwen was niet markt gerelateerd, zoals onbetaalde huishoudelijke arbeid of productie voor eigen gebruik. Maar informatie hierover is lastig, soms onmogelijk, te achterhalen in de bronnen. Deze onzichtbaarheid leidt tot de keuze voor de aandacht voor betaalde arbeid buiten de huishouding.

\section{Werkende vrouwen in de Republiek: de context van het onderzoeksproject}

Het beeld dat reizigers schetsten van vrouwen in de Republiek was niet eenduidig. Maar wat was nu eigenlijk de norm over werkende vrouwen? Die lag vooral binnenshuis, in het leiden van het huishouden, terwijl mannen de rol van kostwinner was toebedeeld. Deze verdeling was volgens vroegmoderne moralisten het ideaal. Toch gingen zij zeker niet voorbij aan de mogelijkheid dat vrouwen werkten. Het ideaal van de toegewijde echtgenote en moeder was in de zestiende eeuw niet onbekend en werd ook uitgedragen, maar tegelijkertijd was er ook ruimte voor beelden van werkende vrouwen, zoals duidelijk blijkt uit de bijdrage van Annette de Vries in dit themanummer.

De voorgeschreven sekserollen waren niet rigide. ${ }^{5}$ Dat werden ze pas met de opkomst van het huiselijkheidsideaal, met de verheerlijking van het huiselijke huwelijksgeluk waarin vrouwen als echtgenote en moeder een belangrijke taak was toebedacht, dat de privé-sfeer tot haar domein bestempelde en de openbare sfeer aan mannen voorbehield. De kern van het ideaal was niet nieuw, maar de sekserollen werden toen scherper gedefinieerd en het ideaal breder gepropageerd. ${ }^{6}$ Het huiselijkheidsideaal wordt onder meer gerelateerd aan de opkomst van de burgerij, voor en door wie het ideaal voornamelijk uit-

5. Donald Haks, Huwelijk en gezin in Holland in de 17de en 18de eeuw (Utrecht I985) I50-I52.

6. Deborah Simonton, A history of European women's work, 1700 to the present (Londen/ New York I998) 87-88; Dorothée Sturkenboom, Spectators van hartstocht. Sekse en emotionele cultuur in de achttiende eeuw (Hilversum I998) 317. 
gedragen werd. ${ }^{7}$ Het ideaal deed in Europa opgang vanaf het einde van de achttiende eeuw, maar zou volgens sommige wetenschappers vanwege de vroege opkomst van het burgerlijke gezin in de Republiek, bijvoorbeeld in Holland, al eerder zijn geïntroduceerd. ${ }^{8}$

Maar voor wie gold het ideaal van de niet-werkende vrouw precies en hoe verhield het ideaal zich tot de vroegmoderne praktijk? Een definitief antwoord op deze vragen is er nog niet. Hier en daar zien we de prescriptieve norm terug in het dagelijkse leven. Zo hadden weduwen gerede kans op succes als zij om steun verzochten nadat de 'broodwinner' van het gezin was overleden. ${ }^{9}$ Ook conflicten tussen ouders en kinderen over voorgenomen huwelijken tonen dat men mannen als belangrijkste kostwinners zag. De meest voorkomende reden waarom ouders toestemming voor een voorgenomen huwelijk weigerden, was de verwachting dat hun aanstaande schoonzoon het nieuwe gezin (nog) niet kon onderhouden. Dergelijke verwijzingen naar werk werden alleen door de ouders van meisjes gemaakt. ${ }^{\text {IO }}$ Toch werkten de weduwen die aangaven hun 'broodwinner' te hebben verloren en de aanstaande bruiden zelf vaak ook. Er bestond dus zeker een discrepantie tussen norm en praktijk. Dit betekent dat we ons in het onderzoek naar vrouwenarbeid niet te zeer moeten laten leiden door voorgeschreven idealen. Moralistische opvattingen geven immers een slecht beeld van de realiteit waarin sommige groepen vrouwen leefden - velen werkten en bleven dat doen. Daarnaast dreigt het gevaar dat we te gemakkelijk voorbij gaan aan andere verklaringen voor veranderingen in de arbeidsparticipatie van vrouwen, zoals Myriam Everard in haar artikel in deze bundel toont.

Of Nederlandse vrouwen nu vooral 'actieve onderneemsters' of 'ijverige huisvrouwen' waren, om in de termen van reizigers te blijven, valt te bezien. Er is al vaak op gewezen dat reisverslagen als bron voor historisch onderzoek niet erg betrouwbaar zijn. ${ }^{\text {II }}$ Of buitenlandse waarnemers een representatief beeld schetsten, is onbekend. ${ }^{\mathrm{I} 2}$ Maar er zijn wel andere aanwijzingen dat de positie van Hollandse vrouwen afweek van die van seksegenoten in andere gebieden. De Vries en Van der Woude betogen dat in Nederland de eerste moderne economie ontstond. De Republiek viel op door de sterke verstedelijking, een ont-

7. Zie bijvoorbeeld: Leonore Davidoff en Catherine Hall, Family Fortunes: Men and Women of the English Middle Class, 1780-1850 (Londen I987); Amanda Vickery, 'Golden age to separate spheres? A review of the categories and chronology of English women's history', in: The Historical Journal 36 (1993) 383-4I4.

8. Hettie A. Pott-Buter, Facts and Fairy Tales about female labor, family and fertility. A sevencountry comparison 1850-1990 (Amsterdam I993) 54-55, 285-285; De Vries en Van der Woude, Nederland, 698.

9. Ariadne Schmidt, Overleven na de dood. Weduwen in Leiden in de Gouden Eeuw (Amsterdam 2002) I74.

10. Manon van der Heijden, 'Contradictory interests: Work, parents and offspring in early modern Holland', in: The History of the Family 9 (2004) 355-370, aldaar 359-360. 
wikkeld productieniveau, een wereldwijd handelsnetwerk en een goed geschoolde bevolking. ${ }^{\mathrm{I} 3}$ Met zijn open samenleving, passie voor consensus en afwezigheid van een absolute macht week de Republiek ook in cultureel opzicht af, zoals Willem Frijhoff en Marijke Spies onlangs lieten zien. ${ }^{\text {I4 }}$ Het is niet onaannemelijk dat dit zijn weerslag op werkende vrouwen had.

Tot nu toe is het niet duidelijk in welk opzicht de positie van vrouwen in de Republiek dan anders zou zijn geweest. Uit de literatuur zijn hierover twee, tegengestelde, hypothesen te distilleren. De arbeidsparticipatie van vrouwen in de Republiek zou hoger of juist lager kunnen zijn geweest dan in de ons omringende landen.

Laten we eerst de argumenten doorlopen die de eerste hypothese ondersteunen. De door buitenlanders opgemerkte ondernemingszin en actieve deelname aan het openbare leven kunnen wijzen op een hoge arbeidsparticipatie. Vrouwen waren te vinden in een breed spectrum van beroepen en velen waren in staat in hun eigen levensonderhoud te voorzien. ${ }^{15}$ De bijzondere kenmerken van de Republiek zouden voor de hoge arbeidsdeelname verantwoordelijk zijn. Zo relateerde de historica Anne Laurence het scala aan economische activiteiten dat vrouwen konden verrichten aan de urbanisatiegraad, de mate van commerciële activiteit, het belang van zeevaart en de juridische positie van vrouwen. ${ }^{16}$ De Republiek en vooral de provincie Holland was de sterkst geürbaniseerde regio van West Europa. Het deel van de bevolking dat in de stad woonde was in 1675 gestegen tot maar liefst 60 procent. ${ }^{\mathrm{I7}}$ De hoge urbanisatiegraad genereerde vele niet-agrarische activiteiten en de stedelijke arbeidsmarkt bood vrouwen meer mogelijkheden om buitenshuis te werken dan die op het platteland. De commerciële activiteit in steden stimuleerde de vraag naar nieuwe producten en de productie daarvan verschafte vrouwen meer werkgelegenheid buiten het huishouden. ${ }^{\mathrm{I}}$ Ook de economische specialisatie kan van

11. Els Kloek, 'De geschiedenis van een stereotype. De bazigheid, ondernemingszin en zindelijkheid van vrouwen in Holland (I500-1800)', in: Jaarboek van het Centraal Bureau voor Genealogie 58 (2004) 5-25.

12. De invloed van beschrijvingen van buitenlanders van Hollandse vrouwen was overigens groot. De nog steeds gezaghebbende Alice Clark verwijst naar buitenlandse waarnemers bij haar stelling dat de arbeidsmarktpositie van vrouwen in Nederland beter was dan in Engeland. Alice Clark, Working life of women in the seventeenth century (Londen I992) 35-37, 219-220.

13. De Vries en Van der Woude, Nederland.

14. Willem Frijhoff en Marijke Spies, 1650: Bevochten Eendracht (Den Haag I999).

15. Anne Laurence, 'How free were English women in the seventeenth century?', in: Els Kloek, Nicole Teeuwen en Marijke Huisman (eds.), Women of the Golden Age. An international debate on women in the seventeenth-century Holland, England and Italy (Hilversum I994) I27.

16. Ibidem, I33-I34.

17. De Vries en Van der Woude, Nederland, 84-85.

18. Laurence, 'How free', I34. 


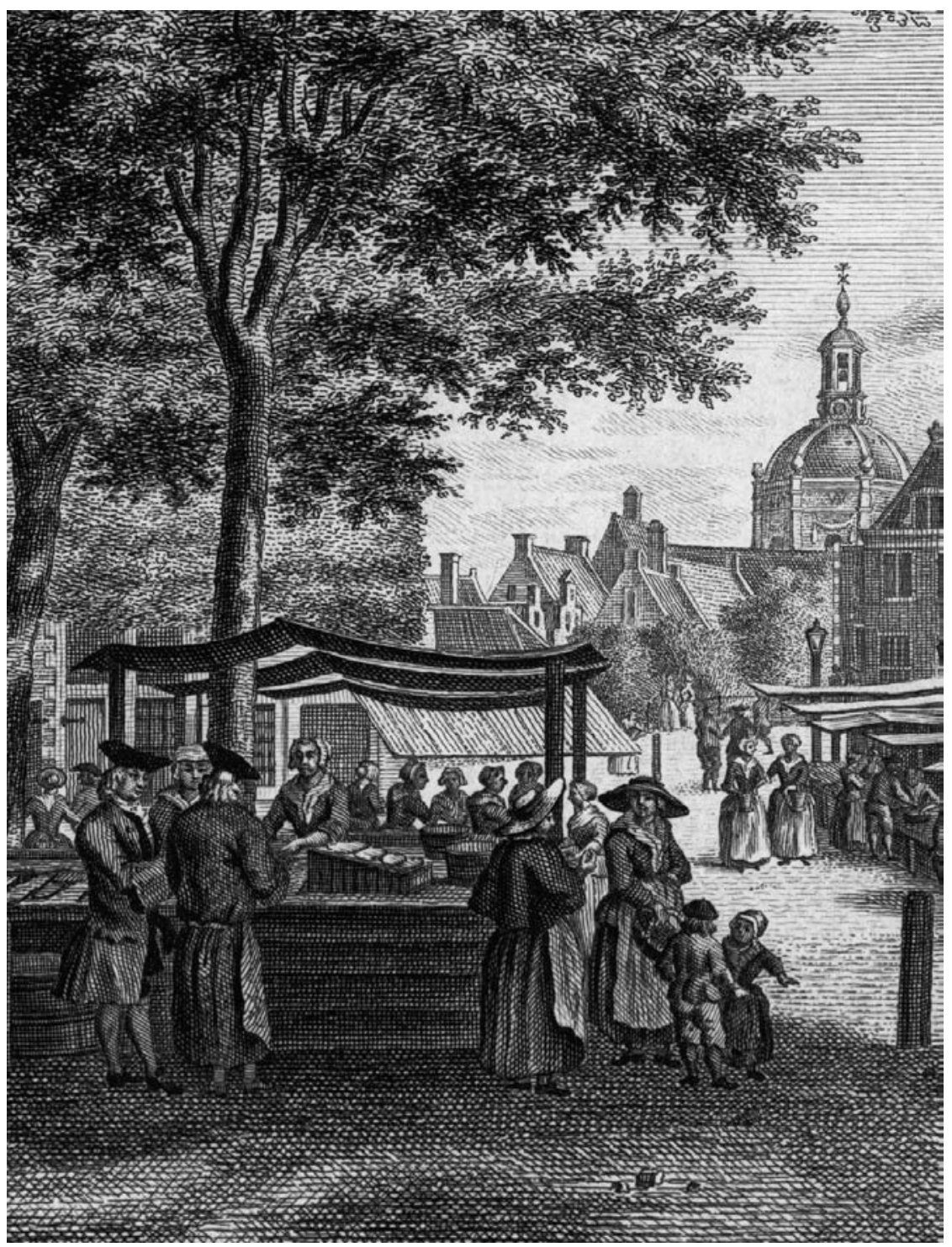

Afb. 1 J. de Beyer, Gezigt op de Vischmarkt, en het fontein, te Leyden, $176_{3}$ (detail).

invloed zijn geweest. Omstreeks 1675 werkte minder dan 40 procent van de bevolking in de landbouw. De ver doorgevoerde arbeidsdeling zorgde voor een sterk gedifferentieerde beroepsstructuur en moet de mogelijkheden voor werkende vrouwen hebben vergroot. ${ }^{\text {I9 }}$

19. De Vries en Van der Woude, Nederland, 606. 
De Republiek was een handelsnatie en vrouwen hebben in die handel ook hun aandeel gehad, als kleine handelaarsters en als koopvrouwen. Vrouwen konden vaak goed zelfstandig de kost verdienen in de handel. In de nijverheid, waar veel in loondienst werd gewerkt, bestonden grote verschillen tussen mannenlonen en vrouwenlonen. Het werk van mannen werd doorgaans hoger gewaardeerd en beter betaald. In de handel daarentegen verrichtte men vooral zelfstandig werk en was het beloningsverschil van minder belang.

Het belang van zeevaart resulteerde in de afwezigheid van veel mannen. Vrouwen namen in afwezigheid van hun echtgenoten diens taken waar. Vele mannen vertrokken met de wic of de voc. Volgens De Vries en Van der Woude was het niet zo dat hun echtgenotes hun plaats innamen: mannen vertrokken juist wegens gebrek aan werkgelegenheid. Maar tweederde van hen keerde niet terug. Dit 'Indisch lek' versterkte de toch al aanwezige ongelijke sekseratio en een grote groep vrouwen moest simpelweg wel zelf met werk in eigen levensonderhoud voorzien. ${ }^{20}$

Het lijkt erop dat de juridische positie van Hollandse vrouwen in vergelijking tot die van vrouwen in sommige andere Europese landen niet ongunstig was. Getrouwde vrouwen stonden onder vaste vrouwenvoogdij. Maar meerderjarige, niet-getrouwde vrouwen waren wel handelingsbekwaam. Zij beschikten zelf over hun goederen, konden contracten sluiten, rechtshandelingen verrichten en brachten alleen bij het voeren van processen een zelf gekozen 'straatvoogd' mee. De beperkte juridische status van getrouwde vrouwen kende enkele belangrijke uitzonderingsregels. Zo waren 'openbare koopvrouwen' waar het hun handel betrof wél handelingsbekwaam. ${ }^{2 \mathrm{I}}$ De juridische positie van zeemansvrouwen leek op die van de openbare koopvrouwen, zoals Annette de Wit in haar artikel over het werk van zeemansvrouwen laat zien. Mannen die vertrokken konden hun echtgenotes machtigen door middel van procuraties zodat hun vrouwen hun zaken konden waarnemen tijdens hun afwezigheid. Een niet onbelangrijke groep vrouwen kreeg hiermee de juridische mogelijkheid zelfstandig op te treden.

In hun artikel over de levensstandaard in de Gouden Eeuw suggereren Leo Noordegraaf en Jan Luiten van Zanden een verband tussen de arbeidsparticipatie van vrouwen en de levensstandaard. Ze veronderstellen dat wegens de grote vraag naar ongeschoolde en laaggeschoolde arbeid vrouwen en kinderen

20. Lotte C. van de Pol, 'The lure of the big city. Female migration to Amsterdam', in: Kloek e.a., Women of the Golden Age, 78 .

21. Ook in erfrechtelijk opzicht kwamen vrouwen in Holland er in verhouding niet slecht vanaf. Zonen en dochters werden redelijk gelijk bedeeld. Hierdoor leverden zowel mannen als vrouwen een belangrijke bijdrage aan de economische basis van een nieuw te stichten gezin. Ariadne Schmidt, 'Vrouwen en het recht. De juridische status van vrouwen in Holland in de vroegmoderne tijd', in: Jaarboek Centraal Bureau voor Genealogie 58 (Den Haag 2004) 26-44. 
op grote schaal werden ingezet in de vroegmoderne kapitalistische economie. Hun betaalde arbeid resulteerde uiteindelijk in een substantiële toename van het inkomen. ${ }^{22}$

Aanhangers van de tweede, tegenovergestelde hypothese, namelijk zij die suggereren dat de arbeidsparticipatie van vrouwen in de Republiek lager was dan in andere West-Europese landen, redeneren precies omgekeerd. Ze opperen de mogelijkheid dat er weinig vrouwen werkten juist vanwege de relatief hoge levensstandaard. Velen konden het zich veroorloven niet te werken. Deze hypothese komt voort uit onderzoek naar een recentere periode. Informatie over de tweede helft van de negentiende en twintigste eeuw toont dat de arbeidsparticipatie van vrouwen in Nederland lager was dan in andere WestEuropese landen. Volgens de econome Hettie Pott-Buter is het aannemelijk dat Nederland deze afwijkende positie al innam sinds de zeventiende eeuw.

In Holland waren industriële activiteiten buitenshuis al vroeg gescheiden van agrarische activiteiten die plaatsvonden rondom het huis. Deze scheiding stimuleerde de praktische realisatie van het ideaal waarin vrouwen zich beperkten tot huishoudelijke werkzaamheden en mannen het inkomen verdienden. Niet werken werd voor vrouwen een statussymbool. Het burgerlijke gezinsmodel dat hier al dominant was in de zeventiende eeuw zou hebben bijgedragen aan een ontwikkeling die Nederland uniek maakte. Door de rijkdom van de Republiek zou het ideaal voor veel vrouwen bereikbaar zijn geweest. Het huiselijkheidsideaal leidde volgens Pott-Buter tot uitsluiting van (vooral middenklasse) vrouwen van betaald werk met uitzondering van de landbouw en het dienstbodenberoep. ${ }^{23}$ Een zelfde suggestie poneren De Vries en Van der Woude: de verklaring voor de veronderstelde lange traditie van lage arbeidsdeelname van vrouwen moet worden gezocht in de pioniersrol die de Republiek vervulde in de ontwikkeling van het burgerlijke huiselijkheidsidee. ${ }^{24}$

Was de arbeidsdeelname van vrouwen in de Republiek nu opmerkelijk hoog of juist opmerkelijk laag? Het is onmogelijk exact vast te stellen hoe groot het aandeel van vrouwen op de vroegmoderne arbeidsmarkt precies was. Statistische gegevens ontbreken voor deze periode en we moeten ons bewust zijn van de onderregistratie van vrouwen in de bronnen uit deze tijd. Bovendien is het bijzonder lastig informatie te achterhalen over vrouwen die níet deelnamen aan de arbeidsmarkt. Maar het is wél mogelijk om met een combinatie van kwantitatieve bronnen, zoals volkstellingen en belastingkohieren en kwalitatieve bronnen zicht te krijgen op minimum aantallen werkende vrouwen,

22. Leo Noordegraaf en Jan Luiten van Zanden, 'Early modern economic growth and the standard of living: did labour benefit from Holland's Golden Age?', in: Karel Davids en Jan Lucassen, A Miracle Mirrored. The Dutch Republic in European perspective (Cambridge I995) 426.

23. Pott-Buter, Facts, 54-55, 66-67, 282-286.

24. De Vries en Van der Woude, Nederland, 698. 
arbeidsdeling naar sekse en ontwikkelingen daarin, de verdeling van vrouwen over economische sectoren en de verschillen tussen vrouwen naar klasse, leeftijd en burgerlijke staat. Wat was de invloed van factoren als economische ontwikkeling, beperkende regels van stedelijke autoriteiten of een huiselijkheidsideaal op de arbeidsdeelname van vrouwen? Op welke manier was de arbeidsdeling binnen het gezin georganiseerd en hoe verhielden bestaansstrategieën van vrouwen zich tot die van mannen of van het gezin waarvan zij deel uitmaakten?

Om deze vragen te beantwoorden, ging op het IISG een project van start waarbinnen onderzoek wordt verricht naar spinsters in de textielnijverheid, het werk van vrouwen in de productie en verkoop van drank, in de handel, in maatschappelijke diensten en de arbeid van arme vrouwen, die leefden aan de onderkant van de samenleving. De vijf onderzoeken bestrijken gezamenlijk bijna de gehele arbeidsmarkt en belichten zoveel mogelijk soorten werk: hooggeschoold, laaggeschoold, goed betaald, slecht betaald, werk in loondienst en zelfstandig ondernemerschap. Uiteindelijk worden de onderzoeksresultaten met elkaar in verband gebracht en om na te gaan of de positie van werkende vrouwen in de Republiek werkelijk zo uniek was als wordt verondersteld.

We hebben ervoor gekozen het onderzoeksproject in te bedden in de context van de geschiedenis van de Republiek. Zonder voorbij te gaan aan de belangrijke vragen die werden gesteld, willen we met deze aanpak ontkomen aan de schijnbaar onoplosbare kwestie over verandering óf continuiteit die het debat over werkende vrouwen zo lang in zijn greep hield.

\section{Historiografie: voorbij het traditionele debat over verandering of continuïteit}

De geschiedenis van de arbeid van vrouwen in Europa is vaak gepresenteerd in termen van verandering óf van continuïteit. Het oude verhaal is al vaak verteld. In navolging van Alice Clark zagen verscheidene historici een voortdurende verslechtering van de positie van vrouwen op de arbeidsmarkt vanaf de Middeleeuwen of Vroegmoderne Tijd. ${ }^{25}$ Met de verandering van productieverhoudingen, de introductie van loonarbeid en de scheiding tussen productie en consumptie zouden vrouwen van de arbeidsmarkt verdrongen zijn. Afwisselend werden het ontstaan van een kapitalistische economie, industrialisatie, economische specialisatie en de opkomst van een huiselijkheidsideaal als verklaring voor die ontwikkeling aangevoerd. ${ }^{26}$

Op deze zienswijze kwam kritiek van historici die benadrukten dat er in al die eeuwen opmerkelijk veel hetzelfde is gebleven in de positie van werkende vrouwen. Mede door de aandacht voor genderrelaties bleek dat er nooit sprake

25. Clark, Working life. 
van gelijkheid tussen seksen is geweest. Men wees op het overheersende patriarchaat als constante. De arbeidsmarkt kenmerkte zich ook tijdens de Middeleeuwen en Vroegmoderne Periode door een arbeidsdeling naar sekse. Ten opzichte van het werk van mannen was het werk van vrouwen ook toen marginaal, laaggeschoold en slecht betaald. ${ }^{27}$

Kritiek op vooral de veranderingsthese nuanceerde de tegenstelling tussen beide interpretaties van de geschiedenis van werkende vrouwen. Het gezin functioneerde in de Vroegmoderne Tijd lang niet altijd als productie-eenheid. Naast het zelfstandige werk binnen de family economy, werd ook loonarbeid verricht. Mannen en vrouwen werkten niet op gelijkwaardige basis samen. ${ }^{28}$ Vrouwen waren te vinden in uiteenlopende sectoren van de vroegmoderne arbeidsmarkt, maar hun werk viel buiten de organisatorische ambachtelijke structuren en vrouwen hadden, anders dan mannen, vaak een zwakke beroepsidentiteit. ${ }^{29}$ De industrialisatie vergrootte de werkgelegenheid voor sommige groepen vrouwen. ${ }^{30}$

De scherpe tegenstelling in het debat werd niet alleen genuanceerd, ook plaatsten historici in de loop van de jaren negentig steeds vaker vraagtekens bij de bruikbaarheid van een analyse in termen van 'verandering' óf 'continuitteit'. Hoewel de termen soms van toepassing zijn, is de waarde ervan als beschrijving van economische geschiedenis van vrouwen over het algemeen te beperkt, concludeerde de historica Pamela Sharpe. Zij bepleit verbreding van het analytische kader. Wat vrouwen nu eigenlijk deden moet bottom-up worden onderzocht, in lokaal georiënteerde case studies waarbij de positie van vrouwen moet worden bestudeerd in de context van de gezinssituatie, demografische

26. Zie Louise Tilly en Joan Scott, Women, work and family (New York I978); Merry Wiesner, Working women in Renaissance Germany (New Jersey I986); Martha Howell, Women, production and patriarchy in late medieval cities (Chicago I986); Bridget Hill, Women, work and sexual politics in eighteenth century England (Oxford I989); Heide Wunder Er ist die Sonn, sie ist der Mond. Frauen in der Frühen Neuzeit (München I992). Volgens Pinchbeck verloren vrouwen weliswaar economische mogelijkheden, maar uiteindelijk zou de industrialisatie als katalysator voor vrouwenemancipatie hebben gewerkt. Ivy Pinchbeck, Women workers and the industrial revolution 1750-1850 (Londen I930).

27. Zie Judith M. Bennet, 'History that stands still: women's work in the European's past', in: Feminist Studies 4 (1988) 269-283.

28. Zie voor een overzicht: Ad Knotter, 'Problemen van de family economy. Gezinsarbeid en arbeidsmarkt in pre-industrieel Europa', in: M. Baud en Th. Engelen (eds.), Samen wonen, samen werken? Vijf essays over de geschiedenis van arbeid en gezin (Hilversum I994) 45-48; Catharina Lis, 'Gezinsarbeid en vrouwenarbeid tijdens een versnellingsfase in de ontwikkeling van het kapitalisme, I750-I850', in: Tijdschrift voor Sociale Geschiedenis 36 (I984) 380-405.

29. Davis, 'Women in the arts mecaniques', I58; E.M. Kloek, Wie hij zij, man of wijf. Vrouwengeschiedenis en de vroegmoderne tijd (Hilversum I990) 74-77.

30. Maxine Berg, 'What difference did women's work make to the Industrial Revolution?', in: History Workshop Journal 35 (I993) 22-44. 
omstandigheden, ideologische veranderingen, de structuur van de lokale gemeenschap en arbeidsmarkt. Om het niveau van de case study te overstijgen moet het onderzoek in een vergelijkend perspectief worden geplaatst en ingepast worden in de context van de economische geschiedenis. Op die manier is het mogelijk een beter inzicht krijgen in de samenlevingen en economieën waarin vrouwen (en mannen) in het verleden werkten en leefden. ${ }^{3 \mathrm{I}}$ Met deze nieuwe benadering onderzocht Sharpe een oud thema: de invloed van het kapitalisme op de werkgelegenheid van vrouwen. In haar studie naar Essex en omgeving keek ze naar ongehuwde en gehuwde vrouwen en weduwen, naar verschillende beroepen, naar stad en platteland en betrok ze thema's als arbeidsdeling naar sekse en de- en reïndustrialisatie. Hieruit bleek dat het toenemende kapitalisme enerzijds marginalisering van vrouwen teweegbracht, maar tegelijkertijd zorgde voor de uitbreiding van niches die vrouwen nieuwe mogelijkheden boden om een inkomen te verdienen, zoals in de kledingindustrie, delen van de landbouw of het bestaan van dienstboden. 'Adapting to capitalism' zo concludeert Sharpe, was geen lineair proces. ${ }^{32}$

In haar boek A bitter living neemt Sheilagh Ogilvie eveneens afstand van de veronderstelling dat seksespecifieke arbeidspatronen door grote macrosystemen worden bepaald. Zij plaatst haar onderzoek naar werkende vrouwen in het Duitse Würtemmberg niet in het kader van verandering óf continuïteit, maar stelt dat de economische activiteit van vrouwen fluctueerde en afhankelijk was van de individuele keuzes van mensen in het indelen van hun tijd. Deze keuzes maakten zij in een kader van (variërende) technologische, culturele en - vooral - institutionele beperkingen. Veranderingen in het kader beinvloedde de keuzes en kunnen de (niet rechtlijnige) veranderingen in seksespecifieke arbeidspatronen, de expansie of contractie in de arbeidsparticipatie van vrouwen verklaren. Om te begrijpen welke factoren van invloed waren op de arbeidsdeelname van vrouwen moet hun situatie dus binnen de sociale en economische context worden geanalyseerd. De belangrijkste factor in de seksespecifieke arbeidsdeling was de institutionele structuur van de samenleving, zo stelt Ogilvie. Instituties als gilden en lokale gemeenschappen, die in Würtemmberg een sterke positie hadden, sloten vrouwen uit. Tot slot bekijkt Ogilvie de wijdere implicaties van de economische positie van vrouwen en concludeert ze dat de beperkingen die vrouwen in Würtemmberg werden opgelegd niet alleen vrouwen zelf benadeelden, maar uiteindelijk een negatieve

31. Pamela Sharpe 'Continuity and change: women's history and economic history in Britain', in: Pamela Sharpe (ed.), Women's work. The English experience 1650-1914 (Londen I998) 27, 33 .

32. Pamela Sharpe, Adapting to capitalism. Working women in the English economy, I700I850 (Londen I996) 6, I49-I50. 
invloed op de ontwikkeling van de gehele Würtemmbergse economie hebben gehad. $^{33}$

Historici, vooral in Engeland, hebben afstand genomen van het oude debat en kiezen andere perspectieven om het werk van vrouwen te bestuderen. Aandacht voor de economische rol van vrouwen breidde zich bovendien uit van alleen arbeid naar onderwerpen als consumptie, eigendomsrechten en bezit. ${ }^{34}$ Hoe is de stand van zaken in Nederland? De onderzoeker die zich hier bezig houdt met het werk van vrouwen in de Vroegmoderne Tijd wordt geregeld gevraagd of 'de' positie van vrouwen op de arbeidsmarkt toen beter was. Studenten - overigens een zeer actieve groep in het onderzoek naar vrouwenarbeid - worstelen in scripties over werkende vrouwen met de historiografische traditie of vallen Clarks zienswijze aan. ${ }^{35}$ De vraag naar verandering óf continuïteit als perspectief voor de geschiedenis van werkende vrouwen is hier nog niet helemaal van de baan. Dit komt waarschijnlijk doordat zowel het onderzoek als de theorievorming minder ver gevorderd zijn dan in Engeland. Toch werd ook hier al lange tijd geleden kritiek geuit op het interpretatiekader. Niet alleen het onbehagen zich te mengen in een ideologisch geladen discussie met wortels in een marxistisch-feministische ideologie leidt tot huiver voor stellingnamen. Ook drong de vraag zich op of verandering of continuïteit van de positie van werkende vrouwen wel de juiste context biedt om de geschiedenis van werkende vrouwen te begrijpen. Al in I99० schreef Els Kloek: 'Steeds opnieuw lijkt het vrouwenhistorisch onderzoek verstrikt te raken in de onmogelijke kwestie hoe ontwikkelingen beoordeeld moeten worden: ten goede of ten kwade'. ${ }^{36}$ Mede doordat bronnen geen uitsluitsel geven, kwamen historici afhankelijk van gelegde accenten tot totaal verschillende interpretaties. Kloek pleitte ervoor 'sekse' in de specifieke historische context

33. Sheilagh Ogilvie, A bitter living. Women, markets, and social capital in early modern Germany (Oxford 2003) 6, I3-I4; 334-352.

34. Amy Erickson, Women and Property in Early Modern England (Londen I993); Jan de Vries, 'Between purchasing power and the world of goods: understanding the household economy in early modern Europe', in: John Brewer en Roy Porter (eds.), Consumption and the world of goods (Londen en New York I993) 85-I32.

35. Zie bijvoorbeeld: Helene Hubers, Zij prijst haar waar. Antwerpse visverkoopsters in de zestiende en zeventiende eeuw, doctoraalscriptie (Universiteit Utrecht I99I); Marieke Zech, De werkende vrouw in getal en beeld. Vrouwen en de boekhandel in Amsterdam en Londen, I600-I699, doctoraalscriptie (Universiteit Utrecht 1997); Marjolein van Dekken, Bier maakt het leven goed. De sociale positie van bierbrouwsters in de Hollandse steden Haarlem en Gouda gedurende de eerste helft van de zestiende eeuw, doctoraalscriptie (Vrije Universiteit Amsterdam 200I); Nicolien Visser, Utrechtse herbergiersters en dunbiertapsters in de zeventiende en achttiende eeuw, doctoraalscriptie (Universiteit Utrecht I997); Laura Van Aert, "Van appelen tot zeemleer" Koopvrouwen in Antwerpen in de I6de eeuw, Thesisverslag (Universiteit Antwerpen 2002).

36. Kloek, Wie hij zij, 31. 
te plaatsen om van daaruit bestaande interpretaties van de geschiedenis te herzien.

Een pleidooi voor een aanpak met meer oog voor historische variatie is ook te lezen in het overzicht van het debat over het ontstaan van het mannelijke kostwinnerschap van Angélique Janssens uit I998. Zij concludeert dat verwijzingen naar een universeel patriarchaat of het kapitalisme niet houdbaar zijn gebleken. Naast de factor 'tijd' moeten ook variabelen als institutionele beperkingen, seksenormen, patriarchale belangen van mannen en de veranderende structuur van de lokale arbeidsmarkt worden betrokken bij het onderzoek dat verklaringen zoekt voor de opkomst van het mannelijke kostwinnerschap. ${ }^{37}$

Op basis van bovenstaande aanbevelingen uit binnen- en buitenland kan het volgende wensenlijstje voor het onderzoek naar werkende vrouwen worden samengesteld. Generaliserende, schematische verklaringen moeten vervangen worden door interpretaties die (meer) ruimte laten voor lokale en regionale verschillen en temporele variëteit. We moeten onderscheid maken tussen verschillende groepen vrouwen: vrouwen met verschillende sociaal-economische achtergronden, vrouwen op het platteland en vrouwen in de stad, gehuwde en niet-gehuwde vrouwen, poorters en niet-poorters et cetera. Het verdient aanbeveling om werk van vrouwen in een bredere context te bestuderen en ook aansluiting te zoeken bij debatten buiten vrouwengeschiedenis. Ten slotte moeten resultaten van casestudy's in vergelijkend perspectief worden geplaatst.

Wat valt van deze aanpak te verwachten? In plaats van de vraag of 'de positie van werkende vrouwen' nu veranderde of gelijk bleef, lijkt het zinvoller te kijken naar verschillen tussen mannen en vrouwen op de arbeidsmarkt, naar mannenwerk en vrouwenwerk, en de implicaties daarvan voor de economie. De vraag naar verandering is wel interessant, maar lijkt tot op heden onoplosbaar. Een te sterke focus op de kwestie ontneemt ons het zicht op de vraag welk werk vrouwen nu eigenlijk deden. ${ }^{38}$ Op de eerste plaats moet vergroting van empirische kennis in het onderzoeksveld dat sterk door theorievorming werd beheerst, leiden tot een beter en genuanceerder beeld van de economische rol van vrouwen en hun activiteiten op de arbeidsmarkt. Nuanceringen naar sociaal-economische achtergrond, leeftijd en burgerlijke en de comparatieve aanpak zullen laten zien dat de invulling van 'vrouwenwerk' niet altijd en overal hetzelfde was.

Door, op de tweede plaats, het onderzoek te plaatsen in de context van de sociale en economische geschiedenis, wordt het makkelijker die empirische kennis te integreren in de mainstream economische en sociale geschiedenis. Hierdoor kan de geschiedenis van arbeid uiteindelijk worden belicht vanuit

37. Angélique Janssens, 'De mannelijke kostwinner: mythe of historische werkelijkheid? Een overzicht van het debat', in: Tijdschrift voor geschiedenis III (I998) 258-280. 38. Vergelijk de bijdrage Annette de Wit in dit themanummer. 
genderperspectief zodat we kunnen komen tot een beter begrip van de arbeidsmarkt. De geschiedenis van arbeid is niet sekseloos. De veronderstelling dat arbeid voor mannen een andere betekenis had dan voor vrouwen lijkt wel te worden onderschreven, maar tot op heden wordt informatie over vrouwen nog nauwelijks geïntegreerd. In overzichtswerken worden vrouwen behandeld in aparte paragrafen - soms onder vermelding van het feit dat er nu eenmaal weinig bekend is over vrouwen - terwijl de rest over mannen gaat. ${ }^{39}$ Het is belangrijk de kennis te vergroten en vervolgens te integreren en arbeid te onderzoeken vanuit genderperspectief zodat het doorgaans als neutraal gepresenteerde, op zijn best expliciet, maar vaker impliciet sterk mannelijke beeld dat veel historici geven van de arbeidsmarkt kan worden bijgesteld.

\section{Sekse en het onderzoek naar (vrouwen)arbeid in Nederland}

Het is nog te vroeg om algemene uitspraken over vrouwen en werk in Nederland in de Vroegmoderne Tijd te doen. Maar recente ontwikkelingen binnen de Nederlandse historiografie tonen wel dat verbreding van het kader vruchtbaar kan zijn om de arbeidspatronen van vrouwen beter te begrijpen. Na een eerste algemene inventarisatie van werkzaamheden van vrouwen in verschillende sectoren van de vroegmoderne arbeidsmarkt richtte de aandacht zich in de jaren negentig op typische vrouwenberoepen en -beroepsgroepen zoals vroedvrouwen, prostituees, dienstboden, visvrouwen, uitdraagsters en vrouwen in de textielnijverheid. ${ }^{40}$ De laatste jaren verschenen er weinig studies over werk van vrouwen in de Republiek. Recente onderzoeken die zich niet specifiek richtten op vrouwenarbeid, maar wel het genderperspectief hanteerden, leverden niettemin interessante inzichten op.

39. De Vries en Van der Woude, Nederland, 689; Frijhoff en Spies, 1650, 190-192.

40. Jenneke Quast, 'Vrouwenarbeid omstreeks I500 in enkele Nederlandse steden', in: Jaarboek voor vrouwengeschiedenis I (I980) 46-64; A.Th. Van Deursen, 'Werkende vrouwen in een Hollands Dorp', in: De zeventiende eeuw 4 (I988) 3-I6; Thera Wijsenbeek-Olthuis, 'Van priseersters tot prostituées. Beroepen van vrouwen in Delft en Den Haag tijdens de achttiende eeuw', in: Jaarboek voor vrouwengeschiedenis 8 (I987) I73-206; Howell, Women, production and patriarchy; Kloek, Wie hij zij; H.A. van der Borg, Vroedvrouwen in beeld en beroep. Ontwikkelingen in het vroedvrouwschap in Leiden, Arnhem, 's Hertogenbosch, en Leeuwarden 1650-1865 (Amsterdam I992); Lotte van de Pol, Het Amsterdams Hoerdom. Prostitutie in de zeventiende en achttiende eeuw (Amsterdam I996); Van de Pol, 'The lure of the big city'; Marybeth Carlson, Domestic service in a changing city economy: Rotterdam, I680-I780, ongepubliceerde dissertatie, University of Wisconsin-Madison (I993); Kirsten Harmsen en Hélène Hubers, 'En zij verkocht de vis...Visverkoopsters in Utrecht en Antwerpen van de veertiende tot en met de zeventiende eeuw', in: Dinamiek 8 (I99I) 29-40; Hilde van Wijngaarden, 'Barber Jacobs en andere uitdraagsters. Werkende vrouwen in Amsterdam in de zestiende en zeventiende eeuw’, in: Tijdschrift voor vrouwengeschiedenis I6 (I995) 334-347. 


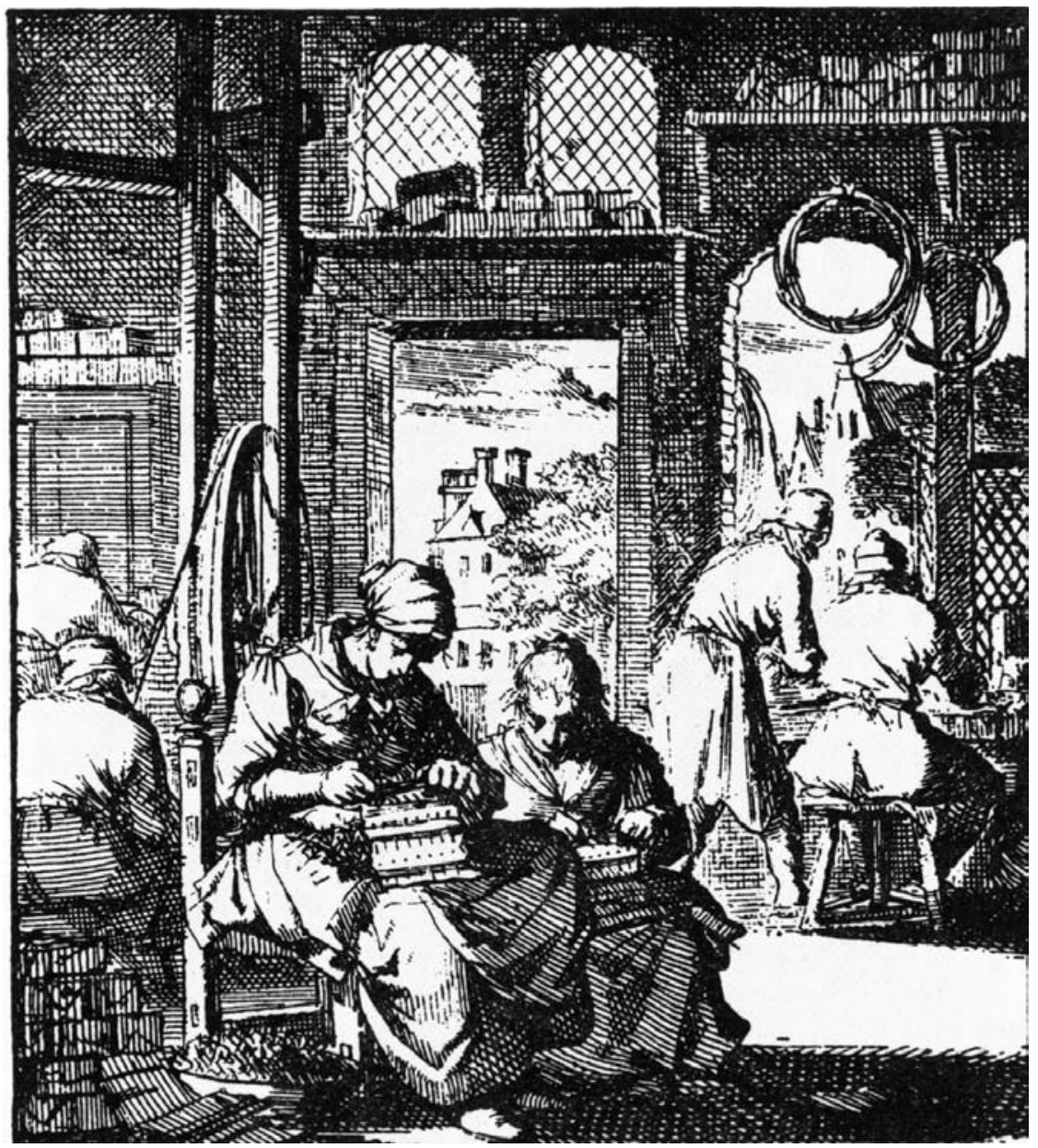

Afb. 2. Jan Luyken, De speldenmaker, 1694.

Studies naar groepen aan de onderkant van de samenleving lieten zien dat het werk van arme vrouwen gekenmerkt werd door een grote mate van flexibiliteit. Vrouwelijke bedeelden in Zwolle en Delft werkten wel, maar verdienden niet genoeg om zichzelf of een gebroken gezin te kunnen onderhouden. Ze hadden zelden een vast dienstverband, werkten vaak thuis, voor een stukloon. Om rond te komen werden verschillende inkomstenbronnen gecombineerd: betaalde arbeid, bedeling en onderlinge hulp. ${ }^{4 \mathrm{I}}$ Ook wat betreft de betaalde arbeid beperkten vrouwen aan de onderkant van de samenleving zich niet tot één

41. Hilde van Wijngaarden, Zorg voor de kost. Armenzorg, arbeid en onderlinge hulp in Zwolle 1650-1700 (Amsterdam 2000); Ingrid van der Vlis, Leven in armoede. Delftse bedeelden in de zeventiende eeuw (Amsterdam 200I). 
bepaalde beroepsactiviteit, zoals Lotte van de Pol liet zien. Losse karweitjes, betaling in natura en fooien speelden een belangrijke rol in wat Van de Pol typeerde als de 'scharreleconomie'. ${ }^{42}$ We kunnen concluderen dat 'beroepsarbeid' niet het juiste kader biedt om de inkomstenverwerving van vooral vrouwen in de laagste klassen te bestuderen. De term is te beperkt en we kunnen beter spreken van werk.

Weduwen ontbeerden per definitie een kostwinner en waren gedwongen om zelf in hun onderhoud te voorzien. De mogelijkheden voor ongehuwde vrouwen, getrouwde vrouwen en weduwen op de arbeidsmarkt waren niet gelijk en dat onderstreept het belang van onderscheid naar burgerlijke staat. Naast enkele gemengde gilden en gilden die zowel vrouwenberoepen als mannenberoepen verenigden, was toegang tot veel gilden voorbehouden aan weduwen die het werk van hun man voortzetten. Veel gilden sloten gehuwde vrouwen uit, maar zij werkten nog al eens binnen het ambacht van hun man en verrichtten dus onzichtbare, maar niettemin productieve arbeid..$^{43}$ Gilden hadden voor mannen een andere betekenis dan voor vrouwen, vrouwenwerk werd anders gedefinieerd dan mannenwerk. Vrouwen werkten vaak wel, maar hadden in tegenstelling tot mannen een zwakke 'beroepsidentiteit'. Voor vrouwen was hun burgerlijke status vaak van beslissende betekenis, terwijl voor mannen opleiding veel belangrijker was.

De incorporatie van vrouwen in gilden verschilde overigens van plaats tot plaats en was afhankelijk van de institutionele verankering van het gildenwezen, zo bleek uit het onderzoek van Bibi Panhuijsen naar kleermakersgilden. De studie onderstreept het belang van aandacht voor regionale variatie. De mogelijkheden van vrouwen binnen de kledingindustrie veranderden in de loop der tijd, maar zijn niet als eenduidige terugdringing te interpreteren. Veranderende consumptiepatronen hadden hun weerslag op de arbeidsdeelname van vrouwen: de toenemende vraag naar vrouwenkleding en niet op maat gemaakte kleding zorgden voor uitbreiding van de markt en het was de expansie van de sector die vrouwen nieuwe arbeidsmogelijkheden bood. ${ }^{44}$

We mogen ons gelukkig prijzen met de recente, geslaagde integratie van gender in het onderzoek naar de Vroegmoderne Periode, maar er valt ook nog een inhaalslag te maken. In vergelijking tot de arbeid van mannen is onze kennis over vrouwenwerk nog te beperkt, zoals ook De Vries en Van der Woude in

42. Van de Pol, Amsterdams hoerdom, II3, 296.

43. Overigens waren weduwen vaak meer dan een intermediair die de bedrijfscontinuiteit garandeerde tussen de dood van een echtgenoot en het volwassen worden van een zoon en behielden ze het bedrijf tot hun dood. Schmidt, Overleven, I2I-I68; Gabrielle Dorren, Eenheid en verscheidenheid. De burgers van Haarlem in de Gouden Eeuw (Amsterdam 200I) IO6-II2.

44. Bibi Panhuysen, Maatwerk. Kleermakers, naaisters, oudkleerkopers en gilden (1500-1800) (Amsterdam 2000) I77-238, 278. 
hun standaardwerk al stelden. ${ }^{45}$ Doel is om daar met het I I S G-onderzoeksproject verandering in te brengen en ook dit themanummer draagt hieraan bij.

De artikelen in dit nummer over vrouwen en werk in de Nederlanden sluiten aan op de thema's binnen de historiografie over vrouwen, mannen en arbeid in de Vroegmoderne Tijd - zoals de (juridische) context van vrouwenwerk, huiselijkheid, verschillen tussen norm en praktijk, arbeidsdeling naar sekse op de arbeidsmarkt en binnen het gezin. De bijdragen passen in de nieuwe benadering van de geschiedenis van het werk van vrouwen en laten zich lezen als een pleidooi voor differentiatie naar plaats, tijd, economische sector, en voor wat betreft de vrouwen naar sociale klasse en burgerlijke staat. Op de vraag aan de auteurs van dit themanummer of zij in hun onderzoeksmateriaal aanwijzingen zagen voor een veranderende positie van vrouwen op de arbeidsmarkt kwamen nuancerende antwoorden. In geen van de onderzoeken bleek er sprake te zijn van een eenduidige ontwikkeling.

De bijdrage van Laura van Aert laat dat bijvoorbeeld duidelijk zien. In haar artikel sluit Van Aert zich aan bij de ontwikkeling in het historisch onderzoek om de context van vrouwenwerk nadrukkelijker in ogenschouw te nemen. $\mathrm{Zij}$ kijkt niet naar vrouwenarbeid an sich, maar verbreedt het blikveld en richt zich op de juridische status van vrouwen. Dit biedt mogelijkheden om de bijzondere status van koopvrouwen te verkennen en te bepalen of vrouwen in de vroegmoderne samenleving vooral 'carriers' dan wel 'creators' waren van onroerend goed. Met uitzondering van Holland weten we nog weinig over de 'wettelijke' bewegingsruimte van vrouwen. ${ }^{46}$ Deze studie naar Antwerpen - de enige in dit nummer buiten de grenzen van de (latere) Republiek - voorziet in informatie voor een vergelijkend perspectief. Van Aert waarschuwt voor generalisaties op geografisch gebied. Van de algemene Europese tendens van een steeds verdergaande juridische beperking van vrouwen was in Antwerpen geen sprake. Opvallende overeenkomsten waren er wél tussen de Antwerpse vrouwen en de vrouwen in Amsterdam. Een vergelijking met de situatie op het platteland zou moeten uitwijzen of dit samenhangt met de belangrijke economische rol die vrouwen in de (op handel gerichte) stedelijke gemeenschap vervulden.

Aandacht voor regionale variatie is ook het devies van Piet van Cruyningen. Dé Nederlandse landbouw bestaat niet. De vier verschillende landbouwsystemen die er in de Vroegmoderne Tijd te onderscheiden waren, kenden elk hun eigen arbeidsbehoefte en verschillende manieren waarop arbeid werd ingezet. Maar dat is niet de enige reden dat er geen algemene uitspraken over vrouwen in de agrarische sector kunnen worden gedaan. De landbouw is er zeer slecht vanaf gekomen in de Nederlandse historiografie over werkende vrouwen en dat

45. De Vries en Van der Woude, Nederland, 689.

46. Schmidt, 'Vrouwen en het recht, 26-44. 
geldt al helemaal voor de Vroegmoderne Tijd. ${ }^{47}$ Evenmin was er binnen de geschiedschrijving over landbouw aandacht voor sekseverschillen. En dat valt te betreuren, zoals Piet van Cruyningen stelt, omdat 'meer kennis over de rol die vrouwen speelden meer inzicht kan verschaffen in het functioneren van het boerenbedrijf. Zijn waardevolle aanzet over vrouwenarbeid in het Zeeuwse commerciële akkerbouwbedrijf laat zien dat evenmin als dé Nederlandse landbouw, dé vrouwelijke arbeidskracht bestond. Vrouwen 'assisteren' hun echtgenoot bij diens werk, heet het vaak in de literatuur, maar deze typering doet geen recht aan de arbeidsverdeling naar sekse op de boerderij. Het werk van vrouwen in het sterk gespecialiseerde akkerbouwbedrijf was afhankelijk van seizoensveranderingen, klasse en van burgerlijke staat. Boerinnen hadden de verantwoordelijkheid over een apart deel van het boerenbedrijf, terwijl landarbeidsters voorzagen in de toegenomen vraag naar arbeid in piekseizoenen.

Een mooi voorbeeld van de winst van de integratie van sekse voor onderzoek naar de vroegmoderne arbeidsmarkt is het onderzoek naar zeevarenden. De heersende veronderstelling van Nederlandse historici dat zeelieden doorgaans ongehuwd waren omdat hun loon ontoereikend was voor het onderhoud van een gezin blijkt niet te kloppen. De veronderstelling ging, ten onrechte, uit van het mannelijke kostwinnerschap. Al waren de inkomsten niet voldoende om van te bestaan, de voc deed wél regelmatig betalingen aan zeemansvrouwen. Achterblijvers combineerden verschillende strategieën om in het levensonderhoud te voorzien. ${ }^{48}$ Annette de Wit leverde met haar onderzoek naar zeevarende gemeenschappen in het Maasmondgebied vanuit genderperspectief een bijdrage aan dit nieuwe historiografische thema. In haar bijdrage aan deze bundel gaat zij op het werk van de achterblijvers in. In het artikel over het werk van zeemansvrouwen laat zij nadrukkelijk ook de relatie met mannenarbeid zien. De regionale opzet van het onderzoek biedt de mogelijkheid de arbeidsmarktpositie van verschillende groepen vrouwen te bestuderen en daarmee komt de onverwacht grote diversiteit aan beroepsmatige

47. Een uitzondering voor de moderne tijd is: M. van der Burg, 'Geen tweede boer'. Gender, landbouwmodernisering en onderwijs aan plattelandsvrouwen in Nederland, 1863-1968 (Wageningen 2002).

48. Roelof van Gelder, Het Oost-Indisch avontuur. Duitsers in dienst van de VOC (Nijmegen I997) 58; Marc van Alphen, 'The female side of Dutch shipping: financial bonds of seamen ashore in the I7th and I8th century', in: J.R. Bruijn en W.F.J. Morzer Bruyns (eds.), AngloDutch Mercantile Marine relations 1700-1850 (Leiden, I99I) I25-I32; Manon van der Heijden, 'Achterblijvers. Rotterdamse vrouwen en de voc (I602-I750)', in: Manon van der Heijden en Paul van der Laar (eds.), Rotterdammers en de VOC. Handelscompagnie, stad en burgers (1600-1800) (Amsterdam 2002) I8I-2I2; Annette de Wit, Seamen and shore women - The maritime household in Dutch seafaring communities of the seventeenth century ongepubliceerde paper (Rijksuniversiteit Leiden I998); Danielle van den Heuvel, "Bij uijtlandigheijt van haar man". Echtgenotes van VOC-zeelieden, aangemonsterd voor de kamer Enkuizen (17001750) (Amsterdam 2004). 
activiteiten van deze vrouwen aan het licht. De economische conjunctuur, professionalisering en verandering van de bezitsverhoudingen binnen de visserij beïnvloedden het werk dat vrouwen deden, maar de uitkomst van deze ontwikkelingen waren niet voor alle groepen vrouwen gelijk. Het onderzoek naar het huishouden in een maritieme samenleving vanuit genderperspectief corrigeert het te eenzijdige beeld van inkomstenwerving van zeelieden, belicht de variëteit aan bestaansstrategieën van huishoudens in zeevarende gemeenschappen en toont dat er tussen mannen en vrouwen vaak sprake was van wederzijdse afhankelijkheid.

Ook de invloed van de opkomst van het huiselijkheidsideaal was niet voor alle vrouwen gelijk. Om de werkelijke invloed te meten en uitspraken te doen over de relatie tussen de opkomst van het ideaal en arbeid moeten we onderscheid maken naar sociale klasse. Tot ver in de moderne tijd combineerden vrouwen in de agrarische sector en kleine zelfstandigen hun bezigheden in het huishouden met beroepsarbeid. ${ }^{49}$ Tijdens de Republiek was de levensstandaard dan relatief hoog, maar toch konden veel vrouwen het zich niet permitteren om niet buitenshuis te werken. Bovendien speelden niet alleen financiële overwegingen een rol. Uit buitenlandse studies is bekend dat het prescriptieve huiselijkheidsideaal weinig vat had op (meer bemiddelde) vrouwen in familiebedrijven. Zij behielden een belangrijke economische functie tot in de twintigste eeuw. ${ }^{50}$

Zowel Myriam Everard als Annette de Vries sluiten aan op dit historiografisch belangrijke thema van huiselijkheid. Beiden bekritiseren de vanzelfsprekendheid waarmee vrouwen en huiselijkheid met elkaar in verband worden gebracht. Everard richt zich daarbij op de dagelijkse praktijk in de achttiende en begin negentiende eeuw en onderzoekt of het huiselijkheidsideaal vrouwen verdrongen heeft uit beroepen die niet als 'huiselijk' of 'vrouwelijk' kunnen worden getypeerd. Zij betreedt hiermee onontgonnen terrein; er is nog nauwelijks onderzoek gedaan naar vrouwen die zware lichamelijke arbeid verrichtten. Everard ontkracht de (vaak impliciete) veronderstelling dat seksespecifieke arbeidspatronen op fysieke eigenschappen - zoals geringe lichaamskracht - terug te voeren zijn..$^{\text {II }}$ Ook gaat er een waarschuwing uit van Everards bijdrage. Het in de negentiende eeuw breed uitgedragen huiselijkheidsideaal verduistert gemakkelijk het zicht op een groep werkende vrouwen wanneer er geen onderscheid naar sociale klasse wordt gemaakt en op mogelijke andere

49. Evelien Walhout en Frans van Poppel, “'De vermelding des beroeps: eene ijdele formaliteit?” Twee eeuwen vrouwelijke beroepsarbeid in Nederlandse huwelijksakten', in: Tijdschrift voor sociale geschiedenis 29 (2003) 330-331.

50. Robert Beachy, 'Business was a Family affair: Women of Commerce in Central Europe, I650-I880', Histoire Sociale, Social History xxxiv (200I) 307-330; Tina Hammer-Stroeve, Familiezoet. Vrouwen in een ondernemerselite, Enschede 1800-1914 (Zutphen 200I).

51. Zie voor een overzicht hiervan Ogilvie, A bitter living, 7-9. 
verklaringen voor veranderingen in de arbeidsdeelname van vrouwen in de loop van de negentiende eeuw.

Ook De Vries bekritiseert de vanzelfsprekendheid waarmee vrouwen met huiselijkheid worden vereenzelvigd. Ze onderbouwt haar stelling met bewijzen uit onverwachte hoek: de beeldende kunst. De Vries richt zich niet op het verschil tussen norm en praktijk, maar op een te eenzijdige interpretatie van het ideaal - en dat is nieuw. Het is opmerkelijk dat men bij beroepsportrettering van mannen automatisch de relatie legt met werk, terwijl men spinnende vrouwen niet met werk maar met huiselijkheid associeert. Door de iconografie van de spinster niet geïsoleerd te bekijken, maar te plaatsen tegen de achtergrond van algemene voorstellingen van arbeid komt de Vries tot een herinterpretatie van het beeld van de spinster: zij verbeeldde arbeidzaamheid. Vrouwelijke deugdzaamheid was in Nederland in de zestiende en zeventiende eeuw niet (alleen) gelegen in huiselijkheid, maar strekte zich uit tot buitenshuis. Vrouwen werden zelfs gebruikt bij de visualisering van de maatschappelijke norm van arbeidzaamheid. Door de betekenis van 'vrouwelijkheid' onder de loep te nemen toont deze bijdrage dat er meer aan de hand is dan dat er een discrepantie bestond tussen beeld (van huiselijkheid) en werkelijkheid (waarin vrouwen nu eenmaal werkten). Het laat zien dat we voorzichtig moeten zijn met een seksegekleurde interpretatie van voorgeschreven idealen.

Dit themanummer is in zekere zin een inventarisatie van de kennis over werkende vrouwen in de Vroegmoderne Tijd uit lopende of recent afgeronde studies. Het gaat over het werk van vrouwen in verschillende regio's. Met aandacht voor het werk van vrouwen in uiteenlopende sectoren beslaan de bijdragen samen een groot deel van de vroegmoderne arbeidsmarkt. De artikelen komen voort uit onderzoeken over uiteenlopende onderwerpen, waarin vrouwenarbeid (meestal) geen centrale plaats inneemt. Daarmee zijn het niet alleen voorbeelden van de bestudering van het werk van vrouwen vanuit een breder kader, van lokaal of regionaal georiënteerde studies die inzicht geven in de belangrijke determinanten van vrouwenmodern vrouwenwerk, maar tonen ze ook wat de winst van integratie van gender in het vroegmoderne onderzoek kan zijn.

\section{Over de auteur}

Ariadne Schmidt (I972) werkt als postdoc en projectleider op het Internationaal Instituut voor Sociale Geschiedenis aan het onderzoeksproject 'Vrouwenarbeid in de Noordelijke Nederlanden in de Vroegmoderne Tijd, ca. I550-I8I5' (zie www.iisg.nl/research/womenswork.html). Zij promoveerde aan de Universiteit van Amsterdam op het proefschrift Overleven na de dood. Weduwen in Leiden in de Gouden Eeuw (Amsterdam 200I).

E-mail: asc@iisg.nl 